\title{
EVSItalia Database of Dry Grasslands
}

\author{
Francesco Spada, Emiliano Agrillo \& Federica Roncalli
}

\begin{abstract}
A database of phytosociological relevés of dry Grasslands of Central Italy (regional districts: Marche, Abruzzo, Molise, Lazio and southern Toscana) is presented (EVSItalia Database of Dry Grasslands, GIVD ID EU-IT-008). The data-set aims to store information from published phytosociological sources, in order to support ongoing reviews based on larger data-sets for comparative classification of Italian vegetation types. The database stores 963 relevés in 4 syntaxa: Festuco-Brometea (708 relevés), TuberarieteaGuttatae (156 releves), Thero-Brachypodietea (92 relevés), and Lygeo-Stipetea (7 relevés). All the relevés were uploaded in the TURBOVEG software for plot databases. Each relevé contains geographical information (ArcGis Database) in the square of the grid of Operational Geographic Units (OGU), corresponding to the quadrates of the Italian floristic grid, precise GPS or toponym localization as well as descriptive records of locations extracted from geographical information systems. The structure of the data-model is used to produce presence-absence or quantitative matrices for classification of communities and their parameterisation over larger areas by geostatistical analysis. Applications of the database will enable to explore patterns of similarity among the distribution of different associations (chorological groups of associations, provincialism), patterns of geographic changes in community distribution along topographical gradients and to test changes in the physical scenario of selected individual communities along geographical gradients. A different insight into the patterns of synonymy and reassessment among syntaxa on the basis of a geographical treatise is expected.
\end{abstract}

Keywords: Italian Vegetation Database; TURBOVEG.

GIVD Database ID: EU-IT-008

Last update: $2012-06-20$

\section{EVSItalia Database Dry Grasslands}

Scope: The data-set aims to store information from published/certified phytosociological sources in order to support ongoing reviews based on larger data-sets for comparative classification of Italian vegetation types.

Status: completed and continuing

Period: $1968-2010$

Database manager(s): Emiliano Agrillo (emiliano.agrillo@uniroma1.it)

Owner: [NA]

Web address: [NA]

Availability: according to a specific agreement

Database format(s): TURBOVEG, ArcGis database

Publication: [NA]

Plot type(s): normal plots

Non-overlapping plots: 963

Total plot observations: 963

Countries: IT: $40.0 \%$

Forest: [NA] — Non-forest: [NA]

Guilds: all vascular plants: $100 \%$

Environmental data: [NA]

Performance measure(s): [NA]

Geographic localisation: [NA]

Sampling periods: [NA]

Information as of 2012-07-12; further details and future updates available from http://www.givd.info/ID/EU-IT-008

Francesco Spada (francesco.spada@uniroma1.it), Emiliano Agrillo* (emiliano.agrillo@uniroma1.it), Federica Roncalli (federica.roncalli@@uniroma1.it)

Department of Environmental Biology, Sapienza University of Roma, Rome, ITALY

*Corresponding author 